\title{
METHODOLOGY FOR ENHANCING RELIABILITY OF PREDICTIVE PROJECT SCHEDULES IN CONSTRUCTION
}

\section{METODYKA ZWIĘKSZENIA NIEZAWODNOŚCI PREDYKTYWNYCH HARMONOGRAMÓW REALIZACJI PRZEDSIĘWZIĘĆ BUDOWLANYCH*}

\begin{abstract}
Construction projects consist in providing new built facilities as well as in maintaining the existing building stock. Reliability engineering in construction encompasses all stages of the structure's life cycle from the earliest concept of the project to decommissioning. The project planning and design stages are aimed at selecting or creating technical and organisational solutions to assure that the built facility meets the sponsor's and the user's requirements; these requirements regulate also the construction process. The result of planning the construction process should be a reliable schedule - immune to disruptive effects of random occurrences, so assuring high probability of the actual processes meeting their predefined deadlines. A practical method of scheduling construction projects should enable the planner to generate schedules resistant to random occurrences, making them reliable so that the users can meet deadlines. The paper presents a proactive methodology for generating construction schedules of enhanced reliability. The methodology covers two fundamental stages. The first stage is a construction duration risk assessment based on a multi-attribute evaluation of operating conditions. The second stage is the allocation of time buffers. An original methodology supporting decisions at each stage is put forward, namely a methodology for evaluating process duration risk level, defining significance of operating conditions, estimating dispersion of process durations, and defining criticality of processes in the schedule. The author proposes a set of measures of schedule robustness to serve as surrogate criteria in the schedule instability cost minimization problem and buffer sizing. The proposed way of allowing for risk and uncertainty in creating reliable schedules is argued to be efficient in protecting the project completion date, as well as stage or even process start dates, against disruptions.
\end{abstract}

Keywords: project programme reliability, construction project scheduling, construction and maintenance of built facilities, robustness, duration risk analysis and assessment, time buffer allocation

\begin{abstract}
Przedsięwzięcia budowlane obejmuja swym zakresem procesy zwiąane z wznoszeniem nowych obiektów, jak $i$ utrzymaniem istniejących zasobów. Inżynieria niezawodności w budownictwie obejmuje wszystkie fazy cyklu życia obiektu budowlanego, od przygotowania koncepcyjnego po jego likwidację. Na etapie planowania i projektowania jest dokonywany dobór rozwiazań technicznych i organizacyjnych, które zapewniq spetnienie wymagań stawianych przez inwestora i użytkownika, w tym również w odniesieniu do fazy realizacji obiektu. Rezultatem projektowania przebiegu realizacji przedsięzięcia powinien być niezawodny harmonogram o wysokim prawdopodobieństwie dotrzymania zaplanowanych terminów i małej wrażliwości na wptyw zjawisk losowych. W artykule zaprezentowano proaktywne podejście metodyczne do projektowania predyktywnych harmonogramów realizacji przedsięwzięć budowlanych, w celu zwiększenia ich niezawodności. Obejmuje ono dwa zasadnicze etapy: ocenę ryzyka czasu realizacji procesów budowlanych w oparciu o wieloatrybutowa ocenę warunków realizacyjnych oraz alokację buforów czasu w harmonogramie. Opracowano oryginalna metodykę wspomagająca podejmowanie decyzji na każdym etapie tej procedu$r y$, tj. metodykę oceny poziomu ryzyka czasu realizacji procesów, określania istotności warunków realizacyjnych, dyspersji czasu realizacji procesów budowlanych i krytyczności procesów w harmonogramowaniu predyktywnym. Zaproponowano zestaw mierników odporności harmonogramu, stanowiących zastępcze kryteria w problemie minimalizacji kosztu niestabilności i określania wielkości buforów czasu. Proponowane ujęcie uwzględnienia warunków ryzyka w harmonogramach predyktywnych zwiększa ich niezawodność i zapobiega dezaktualizacji terminu końcowego oraz terminów realizacji poszczególnych procesów lub etapów przedsięwzięcia.
\end{abstract}

Stowa kluczowe: niezawodność projektu realizacji, harmonogramowanie przedsięwzięć budowlanych, realizacja i eksploatacja obiektów, odporność na zakłócenia realizacyjne, analiza i ocena ryzyka czasu, alokacja buforów czasu

\section{Introduction}

Problems of scheduling construction projects, that involve new construction, modernization as well as maintenance-related activities, stays the object of interest of many research centres $[1,3-5,7,10,14$, 16-18, 20, 22, 24, 26, 28-30]. Over the last decades, one can observe advance of scheduling methods that allow the user to precisely model real-life conditions, mainly resource availability restrictions and effects of random occurrences.

Projects are affected by risk that affect completion dates $[8,11$, $14,16-18,21,24,26-27]$. Striving for reducing impact of random occurrences provides rationale for rapid development of robust methods in statistics and operations research [2], and explains growing popularity of their application in many sectors of economy. An example of these trends in the field of project management are predictive sched-

(*) Tekst artykułu w polskiej wersji językowej dostępny w elektronicznym wydaniu kwartalnika na stronie www.ein.org.pl 
uling techniques with proactive approach [29] aimed at generating schedules resistant to interferences, called robust schedules. They are considered superior to the traditional reactive re-scheduling as disturbances make the initial plans expire.

Schedule robustness is defined as the schedule's ability to stay valid despite minor changes in duration of processes (activities) these changes being due to risk [1]. Two optimization strategies of different focuses are in use [28], namely:

- improving quality robustness aimed at assuring stability of makespan (meeting the predefined completion date),

- improving solution robustness aimed at conducting processes according to the plan; in anticipation of disruptions, the planner strives for minimizing the difference between actual and scheduled activity start dates.

Both of these strategies are intended to improve schedule reliability. The reliability can be defined as the probability of the schedule's meeting expectations towards trustworthiness of planned dates: the project completion date and completion dates of particular processes.

The majority of current construction scheduling practices that assume process durations to be random values focus more on determining the project completion date with a predetermined probability [14, 20] rather than on building schedules with predefined process start dates. An analysis of network models in the function of time provides probabilistic output, which is of little practical use when it comes to contracting works and deliveries. Another difficulty is determination of the process duration probability distribution type and parameters.

Most methods in use: PERT (Program Evaluation and Review Technique), PNET (Probabilistic Network Evaluation Technique), NRB (Narrow Reliability Bounds method) assume that the random variables of process durations are independent, which is a far going simplification. Dawood [6] proposed a simulation-based method to model correlation of process durations as random variables and to improve precision of project duration estimates. Defining duration risk factors as well as assessing their impact on process times are experience based, which requires access to expert knowledge and historical records. Simulations enable the planner to determine the project duration's probability density function and density functions of process durations. It is thus possible to estimate the effect of particular risk factors on project progress. Practicability of Dawood's method is limited by the fact that the planner needs to have (or have access to) considerable experience and knowledge on probability distribution type and parameters of each particular risk factor. Subjectivity, errors in risk evaluation and basing on incomplete risk records would also negatively affect the output of analyses conducted by means of this method.

Nasir et al. [19] put forward a method to facilitate estimating pessimistic and optimistic durations of processes. The method is based on belief networks. Pessimistic and optimistic duration estimates can be than used in PERT analysis or Monte Carlo simulation. The procedure of developing a belief network comprises four steps to be supported by expert opinions: identifying risk factors, identifying risk factor relationships, developing network structure, and calculating conditional probabilities of risk occurrence. However, the authors report that collecting input and defining the network structure for a particular project case took six weeks. From the point of practice, this is a drawback.

Skorupka [26] presented an integrated method of risk identification with qualitative and quantitative risk assessment designed for construction projects (MOCRA). The method facilitates the assessment of risk reduction strategies and enables the planner to distribute residual risk throughout the project plan. The risk related with particular factors is calculated as a product of probability of occurrence and impact. The impact is expressed as duration increase in percent. The idea of risk allocation in MOCRA is based on the assumption that the defined and quantified risk factors that may affect a particular process by increasing its duration can be totalled and directly related to the pessimistic duration estimate. An increase in the pessimistic duration results in the change of the expected duration. If the interference persists, the mode of duration probability distribution can also be shifted. The assumption that risk effects are additive may be difficult to accept in some cases, but the MOCRA's ease of application may be considered an asset by the potential users.

Schatteman et al. [25] described their construction project risk management approach as integrated with proactive scheduling. The results of risk factors identification, analysis and quantification of occurrence frequency and impact on process durations are used in the heuristic procedure of buffer allocation to create schedules that are immune to interruptions (which means they have the lowest instability cost). Reliability of results obtained by the authors depends strongly on the reliability of expert's opinions, as the experience-based data are needed as input. The number of input parameters is considerable, which may result in cumulation of error. However, limiting the number of risk factors to these considered "most important" may reduce reliability of results by ignoring cumulated effect of minor factors.

In general, the attempts to utilize results of risk analysis in scheduling are aimed at improving the planning reliability. Efforts made towards making construction schedules immune to random disturbances are justified by following facts:

1. To employ subcontractors, one needs to provide them with clearly defined conditions of contract - including the date of their starting the job; the dates need to be established well ahead to allow for prior consent of the client.

2. The contractor needs a reasonable resource management basis. Resource employment plans, material procurement or component production plans require deterministic dates.

3. Failing to deliver a project of work package on time (with deadlines defined in a deterministic way) is related with serious contractual penalties.

The above observations inspired the author to develop an original approach to construction scheduling that allows for duration risks.

\section{Proposed methodology of predictive scheduling}

The proposed methodology for predictive scheduling of construction projects is an implementation of risk management concept. The rich literature on the subject of risk provides a variety of risk definitions [23]. The author adopts the approach by Williams and Heins [31] with risk consisting in variability of results and being described by probability distribution of results.

No construction project is risk-free. Risk can and should be managed - minimized, shared, transferred or accepted, but it should not be ignored [27]. There are many guidelines on dividing the process of risk management into steps. However, most approaches indicate that apart from identifying, analyzing and quantifying, the manager needs to develop and implement measures to actively reduce the scale of impact and probability of unfavourable occurrences. A proactive risk management strategy prompts that risk response planning needs to be incorporated into the scheduling process. It may take a form of time buffer allocation.

The proposed construction scheduling methodology comprises two coupled stages:

- duration risk assessment of the processes,

- allocation of time buffers.

The procedure is presented in Figure 1. Each process shown in the figure was provided with specific decision support methodology.

The objective of duration risk assessment is defining the risk profile by describing it explicitly by a duration probability density function for each process. The first stage of the methodology is crucial as it determines any consecutive action and outlays on risk protection. 


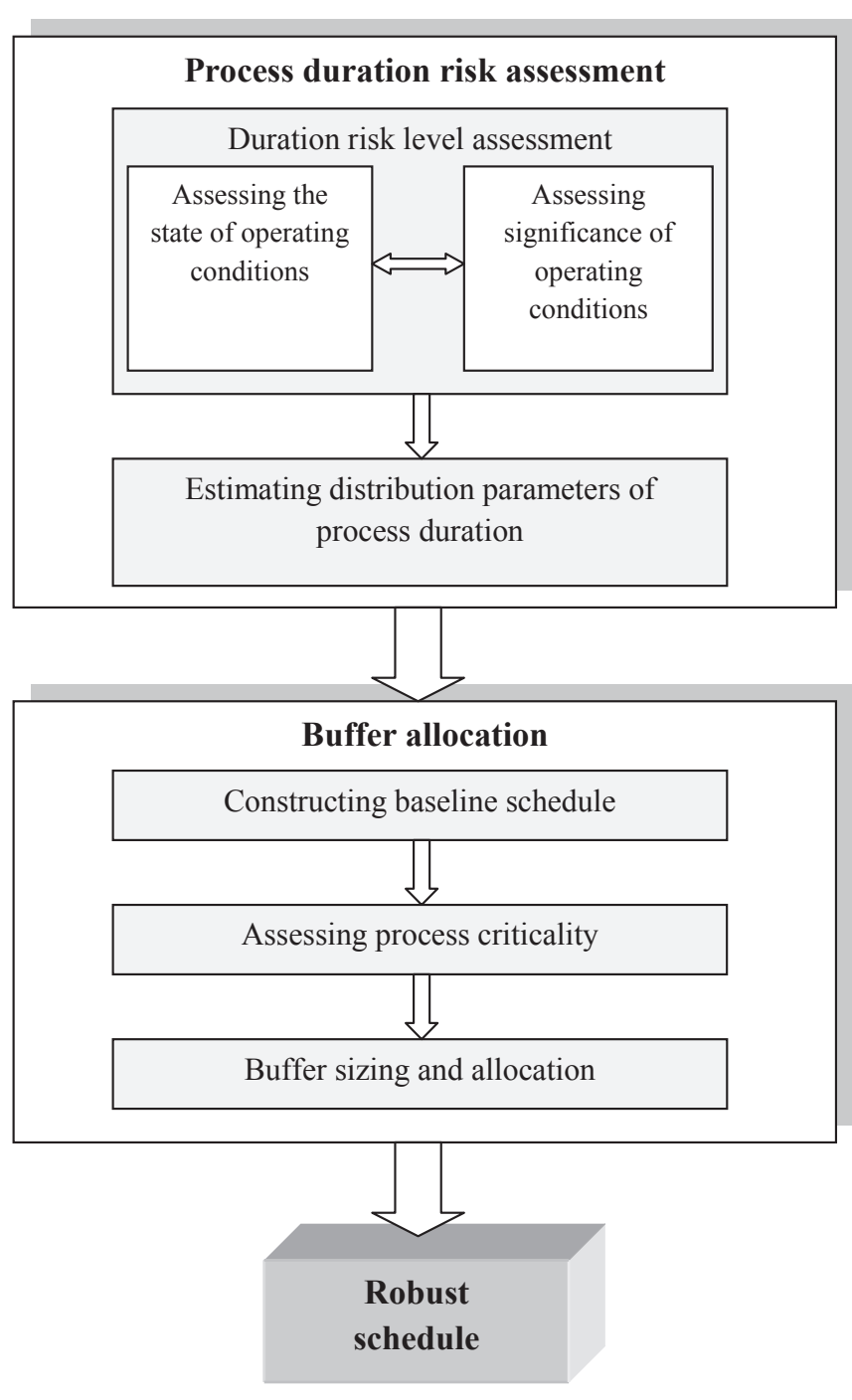

Fig. 1. Stages of predictive scheduling (proposed methodology)

In the classic approach to risk management, the basis of risk assessment is identification of risk sources, called risk factors. Information on actual probability distributions of the risk factors' impact on duration of particular processes is usually difficult to find. Thus, one needs to refer to subjective assessment based on personal experience, intuition or expert opinions.

To identify the set of most significant risk factors affecting duration and start dates of processes, the author conducted a survey among Polish construction practitioners [13].

A literature review and interviews with numerous construction project participants provided the author with a list of 63 potentially significant risk factors to construct a survey questionnaire. The target group for the survey were engineers employed by contractors active in Lublin region, Poland. They were asked to assess frequency of occurrence and impact of the risk factors from the list using a five-point scale (1-5). In the course of the survey, 91 complete questionnaires were returned; the sample size was enough to consider it statistically representative: the minimum sample size was 83 (with $3 \%$ relative error and at $90 \%$ confidence interval).

A significance index (a product of assessment of their impact and frequency of occurrence) was then calculated for each risk factor. As results from the survey, ten most significant risk factors are: winter weather (average significance index of 11.89), precipitation (11.29), delay of preceding works (10.91), shortage of skilled labour (10.33), mistakes and discrepancies in design documents (10.20), client's low

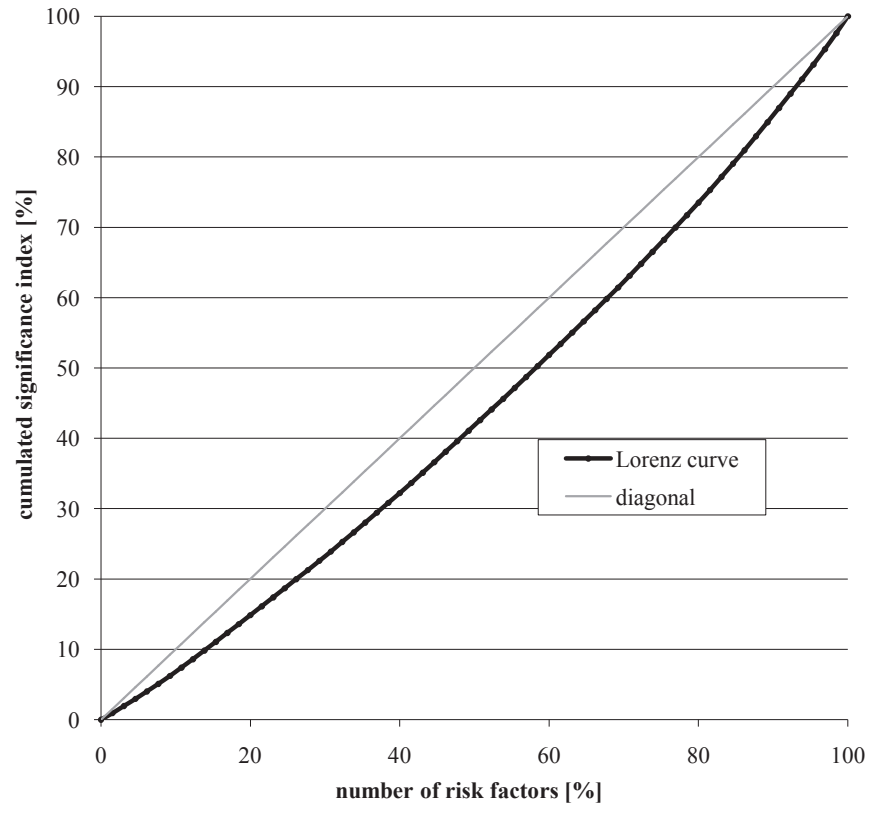

Fig. 2. Lorenz curve for mean risk factor's significance ratios (results of survey) [13]

speed of decision-making (10.13), variations of works scope and quantity due to design changes (10.01), demotivating remuneration system (9.91), client's change of requirements (9.89), difficulty with finding subcontractors (9.49). The risk factors were ordered according to their significance index from the least to the most significant. Figure 2 presents a graph of cumulated significance for this order (Lorenz curve) [13].

A relatively small deviation of the Lorenz curve from its diagonal indicates that concentration of risk factor's significance is low (Gini coefficient of 0.116). Therefore, there exists no small group of risk factors of particularly high impact on project duration. The conclusion is that the assessment of project duration risk cannot be limited to analyzing some set of "most important" factors and ignoring the remaining ones.

The statistical analysis of survey results indicated that experiences of respondents differ (low values of W-Kendall coefficient: 0.238 for the impact and 0.236 for frequency of occurrence indicate that the interviewees' answers are not consistent). Therefore, there is no justification for assuming the same significance of risk factors (so impact and probability of occurrence) for all projects and processes.

The above findings point to serious limitations of the traditional approach to risk factor identification. Because of that, the author proposes a different approach: a multi-attribute assessment of particular project operating conditions.

\section{Methodology of assessing construction duration risk}

The methodology of assessing duration risk of construction processes comprises the assessment of operating conditions, the assessment of significance of these conditions, the estimation of duration risk, and the estimation of distribution parameters of construction processes' durations.

\subsection{Assessment of operating conditions and process dura- tion risk level}

The impact of particular risk factors is the object of analysis of many researchers $[6,25,26]$. Certainly, it is project-specific. It depends on actual conditions and particularities of decision situation [14]. 
Operating conditions, described by the set of qualities, phenomena, states and processes that determine the project or particular process progress, result from the state of the external and internal environment of the project organisation.

Changing even a small part of these conditions may significantly affect project development [17]. For instance, conducting some works during an unfavourable time of the year, may result in stoppage or serious productivity drop due to bad weather (low temperatures, heavy rain/snow). Another instance is the quality of plant and machinery - if poor, failures are more likely, and delays are to be expected.

Appreciating the fact that the frequency of occurrence and severity of impact of risk factors differs from case to case, the author attempted at developing a method for assessing duration risk with respect to particular conditions $[11,13]$.

Table 1 lists identified conditions related with duration risk - ac-

Table 1. Operating conditions affecting the process duration risk level [11, 13]

\begin{tabular}{||c|l||}
\hline \hline No. & Conditions \\
\hline 1 & Time of the year \\
\hline 2 & Experience and availability of resources \\
\hline 3 & Quality of design and specification, quality of construction plans \\
\hline 4 & Quality of project and construction management systems \\
\hline 5 & Quality of remuneration and working conditions \\
\hline 6 & Financial standing of the client and the contractor, project funding \\
\hline 7 & Quality of the supply system \\
\hline 8 & Location and space constraints of the construction site \\
\hline 9 & $\begin{array}{l}\text { External conditions (state of the economy, political climate, legal } \\
\text { conditions, geographic location, availability of suppliers and coop- } \\
\text { erating organizations) }\end{array}$ \\
\hline 10 & Quality and availability of plant and equipment \\
\hline \hline
\end{tabular}

cording to research presented in the literature and according to surveyed experts.

The proposed methodology assumes that the analysis and assessment of operating conditions is the basis for the duration risk assessment.

The author decided to rate the state of each condition in a fivepoint scale $(0 ; 0,25 ; 0.5 ; 0.75 ; 1) .0$ means most desirable state (positive effect on project progress, reduction of process times), 0.5 represents average state (meeting standard productivity rates), 1 stands for an unfavourable state (the condition increases the process duration). The remaining marks are to be used for intermediate states.

The assessment of a condition's state and significance can be conducted for groups of processes of similar susceptibility to this condition. It should be as objective as possible. The author recommends resorting to opinions of a number of experts, and using methods supporting group decision making processes, e.g. Delphi.

As the number of conditions to be considered with each process group is considerable, an aggregated rating of project operating conditions, $P C$, was proposed. It is expressed by a following formula::

$$
P C=\sum_{i=1}^{n} p c_{i} \cdot w_{i}
$$

where: $P C$ - aggregated rating of project operating conditions,

$p c_{i}$ - rating of a state of project condition $i$,

$w_{i}-$ weight of project condition $i$,

$n$ - number of project conditions $(n=10)$.
The aggregated rating is a measure of the process duration risk level. The estimates made this way allow for the overall operating conditions and for significant cumulation of the impact of secondary conditions.

\subsection{Assessment of operating conditions significance}

The significance of a particular operating condition in the process of assessing duration risk level is proposed to be expressed in the form of condition weights.

The weights for the whole set of operating conditions can be determined by means of Analytic Hierarchy Process (AHP). As the method cannot directly account for risks of incomplete information, subjectivity of assessment, and discordant opinions of experts, the author put forward a fuzzy extension of AHP [9].

This fuzzy AHP assumes that the number of experts involved in the decision process is $K$. Each expert provides $m=n(n-1) / 2$ pairwise comparisons of operating conditions' significance, using the usual AHP scale of 1/9,1/7, 1/5, 1/3, 1, 3, 5, 7, 9; optionally, the scale can be extended by intermediate scores of $1 / 8,1 / 6,1 / 4,1 / 2$, $2,4,6,8$. A result of the pairwise comparison is a set of $K$ matrices $\mathbf{A}_{k}=\left\{a_{i j k}\right\}, i=1,2, \ldots, n-1, j=2,3, \ldots, n, j>i, k=1,2, \ldots, K, \quad$ where $a_{i j k}$ represents a preference of condition $i$ over condition $j$ (so a quotient of weights of condition $i$ and $j$ ) according to expert $k$, expressed by means of the above mentioned scale.

This is done to define the vector of crisp weights for particular conditions, $\mathrm{w}=\left[w_{1}, w_{2}, \ldots, w_{n}\right]^{T}$ on the basis of the expert's pairwise judgments.

Relative preferences on conditions, aggregated on the basis of each expert's judgments, are expressed as fuzzy numbers $\tilde{a}_{i j}$. Their membership functions are $\mu_{a_{i j}}(x) \in[0,1]$, with characteristic points defined according to the following formulas [9]:

$$
\begin{aligned}
& l_{i j}=\min _{k=1,2, \ldots, K}\left\{a_{i j k}\right\} \\
& m_{i j}=\left(\prod_{k=1}^{K} a_{i j k}\right)^{1 / K} \\
& u_{i j}=\max _{k=1,2, \ldots, K}\left\{a_{i j k}\right\} .
\end{aligned}
$$

The membership functions are constructed to model non-uniform distribution of the expert's opinions. Figure 3 presents an example of such a membership function.

The vector of condition weights for a finite number of $\alpha$-cuts of the membership function is determined in a way that assures meeting the following condition (in the fuzzy sense):

$$
l_{i j}(\alpha) \tilde{\sim} \frac{w_{i}}{w_{j}} \stackrel{\sim}{\leq} u_{i j}(\alpha), \quad i=1,2, \ldots, n-1, j=2,3, \ldots, n, j>i
$$

Thus, for each expert, $w_{i} / w_{j} \stackrel{\sim}{=} a_{i j k}$, the consistency of an expert's opinion with the opinions of the group is improved. 


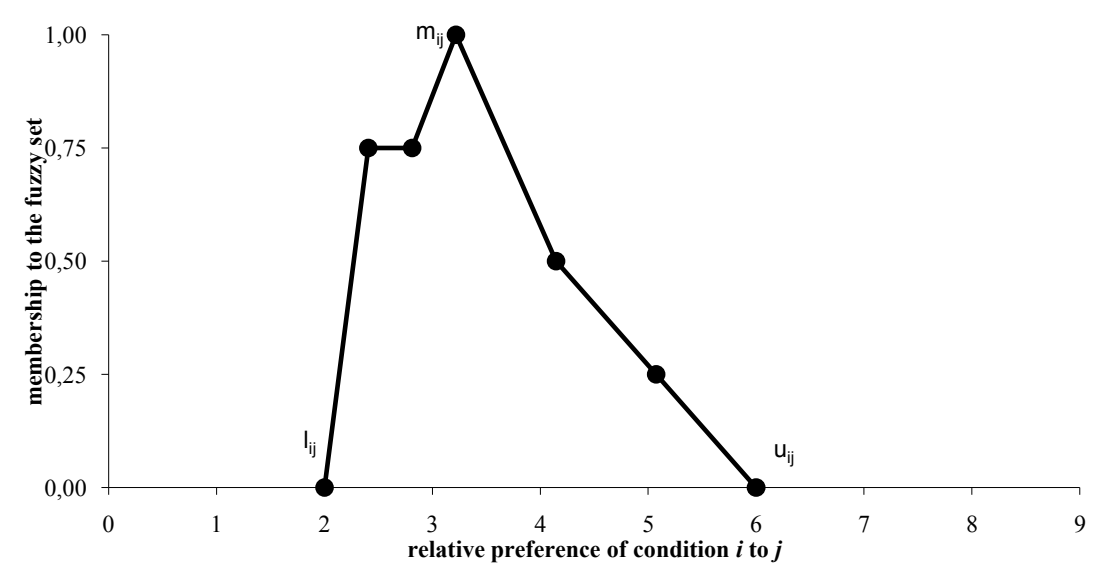

Fig. 3. Membership function for aggregated opinion $\tilde{a}_{i j}$ (example)
It was assumed that duration of a process $j$ that lacks historical input for statistical analysis can be described by a triangular distribution. Its parameters are $a_{j}^{P C}, m_{j}^{P C}, b_{j}^{P C}$, meaning consecutively: the minimum, the mode, and the maximum of duration at a particular aggregated assessment of project conditions state that equals $P C$.

To define the probability density function pa-

rameters of a process's duration, $f_{j}^{P C}(x)$, at any state of project operating conditions $(P C \neq 0,5)$ calculated according to Formula 1, the author used the least squares method and took the following assumptions [11]:

- The risk of defining the process duration to be $t_{j}$ is

\subsection{Assessing dispersion of construction process duration}

To create construction schedules one needs to assume crisp values of process durations. However, durations are not deterministic and can be modelled as random variables of unique distributions. To determine actual distribution type and parameters of a construction process duration, one could conduct series of time-consuming and costly measurements on site. With these being usually unavailable, the researchers base on simplifying assumptions $[6,19,25,26]$.

For instance, authors of PERT assumed that process durations are random variables of beta-PERT distribution with parameters defined on the basis of pessimistic, optimistic and most probable estimates provided by experts. Johnson [15] argues that, without much loss on reliability, beta-PERT can be replaced by an even simpler triangular distribution, described by simple analytical relationships more understandable for scheduling practitioners. To explicitly define a triangular distribution, one needs to estimate the minimum duration, $a_{j}$, the most probable duration (the mode $m_{j}$ ), and maximum duration $b_{j}$.

The proposed approach assumes that minimum and maximum durations can be derived from historical records gathered by a contractor. The mode (with assumption of average operating conditions) can be calculated on the basis of standard productivity rates (median). The assessment of a construction process duration risk is aimed at defining the scale of possible increase of duration and estimating the probability of such occurrences. The risk, as defined by Williams and Heins [31], can be described by means of a delay's probability density function.

The author assumed that scheduling a particular process $j$ to last $t_{j}$, (so taking a particular crisp value of process duration) is related with risk; the risk's measure is the expected value of the process's extension [11]:

$$
r^{P C}\left(t_{j}\right)=\int_{t_{j}}^{b_{j}^{P C}}\left(x-t_{j}\right) \cdot f_{j}^{P C}(x) d x,
$$

where: $\quad r^{P C}\left(t_{j}\right)$ - measure of risk related with scheduling a process $j$ to take $t_{j}$ units of time at the aggregated assessment of the state of project operating conditions being $P C$, calculated according to Formula 1;

$f_{j}^{P C}(x)$ - probability density function for duration of process $j$ at the aggregated assessment state of project operating conditions of $P C$. directly proportional to the assessment of project operating conditions state $P C$, and in most favourable (perfect) conditions it equals 0 . Therefore:

$$
r^{P C}\left(t_{j}\right)=r^{0,5}\left(t_{j}\right) \cdot \frac{P C}{0,5}, \quad \forall t_{j} \in\left[a_{j}^{P C}, b_{j}^{P C}\right] .
$$

- If $P C>0,5$, then the minimum duration $a_{j}^{P C}$ and the mode of duration $m_{j}^{P C}$ may be greater than these at $P C=0,5$.

- If $\mathrm{PC}<0,5$, then the maximum duration $b_{j}^{P C}$ and the mode of duration $m_{j}^{P C}$ may be lower than at $P C=0,5$.

A set of graphs was developed to enable the user to define parameters of random variables of standardised triangular distribution at different aggregated assessment of project operating conditions state. The parameters can be defined for any assessment of the minimum, the mode and the maximum at average conditions. These parameters are necessary input for Monte Carlo simulations and calculating a measure of process criticality. An example of such graphs is given in Figure 4.

\section{Methodology of allocating time buffers}

The stage of buffer allocation comprises: creating the baseline schedule, assessing criticality of processes in the schedule, buffer sizing, and allocating buffers in the robust schedule.

\subsection{Creating baseline schedule}

To create a robust schedule of a project, one needs to start with presenting the project in the form of a network model. Precedence relations between activities are modeled by a direcded, acyclis uni-

graph $G=\langle V, E\rangle$, with no loops, with single initial and single final node. $V=\{1,2, \ldots, n\}$ is a set of the graph nodes (representing construction processes). $E \subset V \times V$ is a relationship defining process sequence; it results from technological and organisational constraints and is a set of the graph's arches. Network techniques are used in construction to model projects of various character: complex of operations type, composed of one-off discrete processes, as well as projects with repetitive operations. Planning the latter is often based on methods that come in many variations and under many names (e.g. time couplings method) and are aimed at harmonization of work. For 


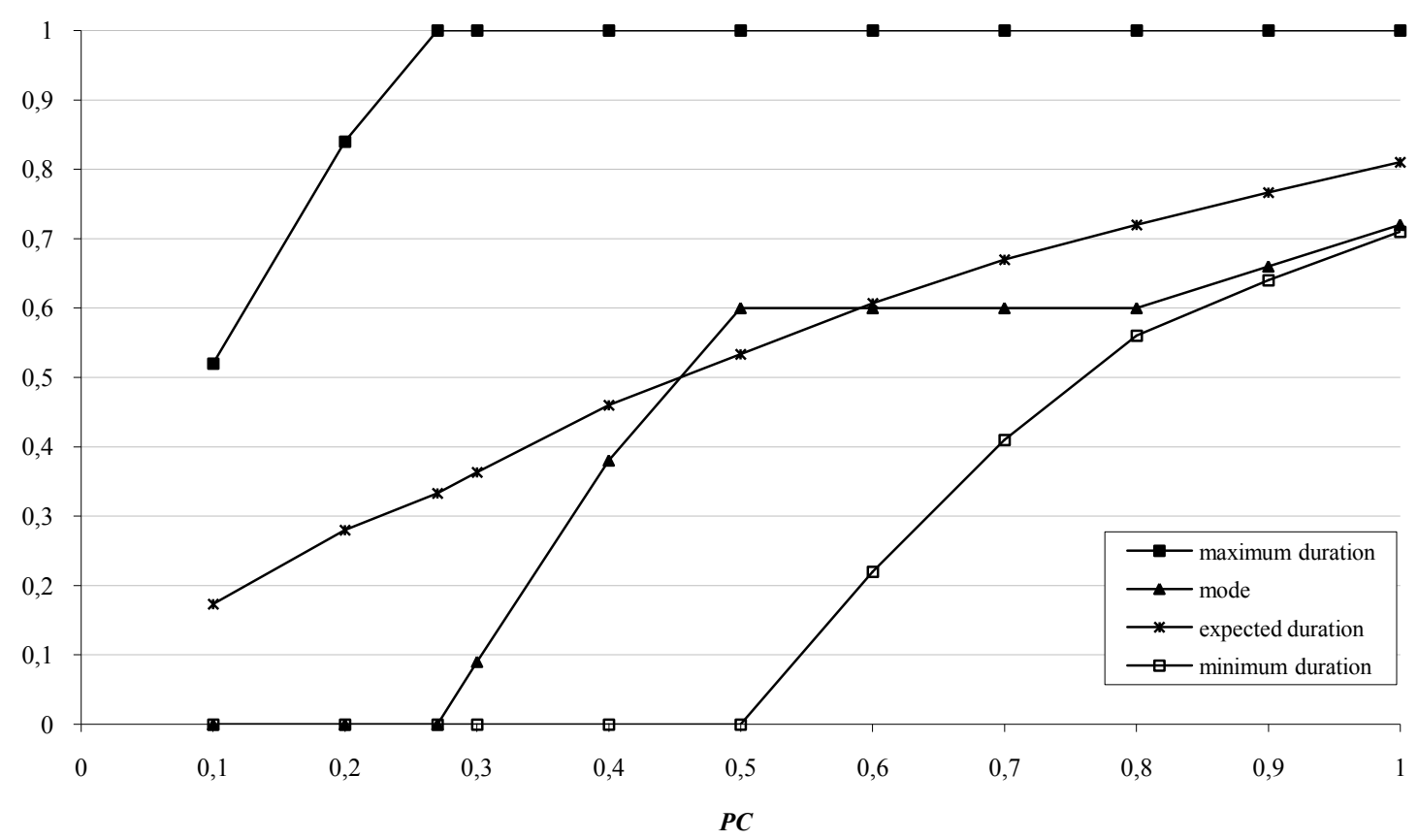

Fig. 4. Relationships between the aggregated assessment of project operating conditions state PC and the parameters of a standardised triangular distribution of the duration of process $j$ conducted in these conditions (for $a_{j}^{0,5}=0, m_{j}^{0,5}=0,6, b_{j}^{0,5}=1$ )

such repetitive projects, identification of organizational relationships between processes should account for resource flows from operation to operation and from location to location. The processes are to be assigned durations corresponding to the expected values $d_{j}(\forall j \in V)$ of random variables whose parameters are to be defined according to the method presented in chapter 3.3. Figure 5 presents a network model of a project to serve as illustration of the approach. The analysis of the network model in the function of time leads to calculating the shortest possible duration of the project, $T_{\min }$, the processes' early starts, and the processes' floats. These can be used for creating a baseline schedule with processes' starts $s_{j}^{0}(\forall j \in V)$ staying within total float limits. In the example, the baseline schedule uses early starts for all activities, and the shortest project duration is 277 days.

\subsection{Assessing criticality of processes}

The proposed methodology defines the process criticality as the susceptibility of a process's start to being delayed causing a change to the schedule. The magnitude of criticality is related with the scale of likely delays. Thus, critical processes need to be scheduled in a way that protects their start dates from being affected by disturbance. Criticality of a process is determined by the structure of the network model and by variability of durations of processes located in network paths that meet before the process starts. To allow for the impact of the predecessor's duration variability on the successors' start dates, the author used the Monte Carlo simulation. Simulation enabled modelling cases with some processes not being allowed to start before dates stated in the baseline schedule (railway policy).

The procedure of assessing a process's criticality consists in simulating the project's development according to the network model with an assumption that process durations are random variables of predetermined parameters (for particular state of project operating conditions), and that processes are allowed to start according to a predefined policy at times stated in the baseline schedule. Simulations provide the scheduler with estimates of expected values of start delays:

$$
\Delta s_{j}=s_{j}^{1}-s_{j}^{0},
$$

where: $\quad s_{j}^{1}$ - mean start of process $j$ determined in the course of simulation experiments,

$s_{j}^{0}-$ start of process $j$ as stated in the baseline schedule.

The measure of a process start's susceptibility to delay (so the measure of the process's criticality) is defined as follows:

$$
k_{j}=\Delta s_{j}+3 \sigma_{j}
$$

where: $\quad \sigma_{j}$-standard deviation of start of process $j, j=1,2, \ldots, n$.

The value of multiplier by the standard deviation, 3 , follows from the one-sided Chebyshev inequality with an assumption that the probability of the process's $j$ start being delayed by more than $k_{j}$ is lower than 0.1 regardless of the process start's $s_{j}$ distribution type and parameters.

\subsection{Buffer sizing}

To improve the schedule's resistance to random occurrences, one can use the redundancy technique: introduce time buffers (idle time) before processes. The proposed approach to buffer sizing assumes that processes $j=1,2, \ldots, n$ are assigned a unit cost, $c_{j}$, of delaying their start beyond the date defined in the schedule. The processes of $c_{j}>0$ need calculating their criticality values $k_{j}$. These processes are to be started according to the railway policy. The aim is to provide a robust schedule of a predetermined, contractually set completion date $T_{d}$, whose instability cost is minimal:

$$
C=\sum_{j=1}^{n} c_{j} E\left(\mathrm{~s}_{j}-s_{j}\right)
$$




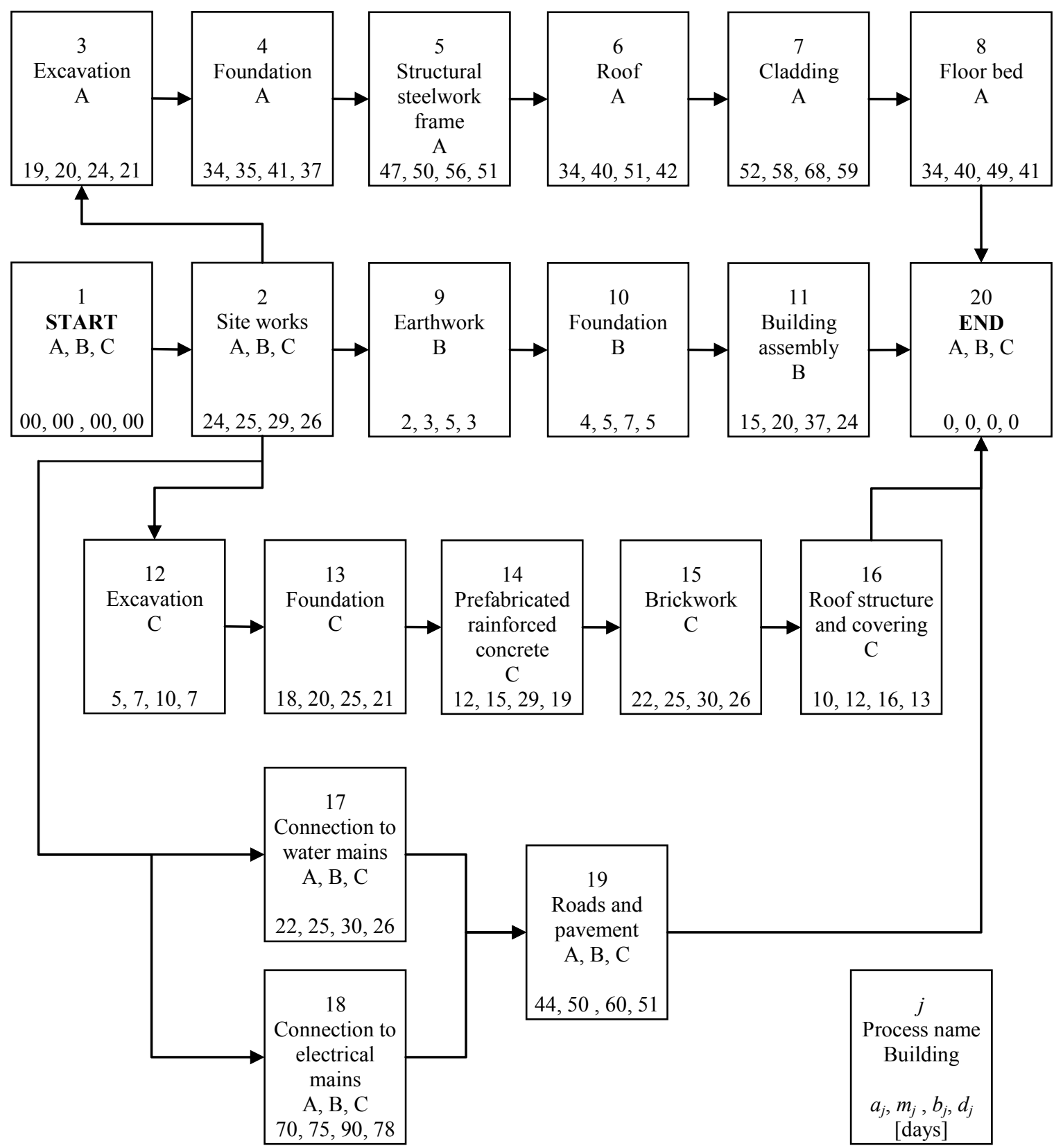

Fig. 5. Project network in the example

where: $\quad \mathbf{s}_{j}-$ a random variable representing the start of process $j$, $s_{j}$ - the process's $j$ start defined in the robust schedule,

$c_{j}$ - unit cost of delaying the start of process $j$ beyond the date stated in the robust schedule.

Considering the form of the objective function (minimizing the expected value of the process delay cost), the decision problem can be solved by means of stochastic programming methods. The complexity of the problem is considerable. Therefore, the author tested a number of substitute measures of robustness aimed at reducing computational effort and providing efficient scheduling algorithms, using these proposed by the literature on the subject, and compared them with measures of his own invention.

Size of buffers $\delta_{j}, j=1,2, \ldots, n$ is determined in the following procedure [10]:

1. Calculate total float $z c_{j}^{0}$ of processes $j=1,2, \ldots, n$ according to the baseline schedule. Total floats of processes $j=1,2, \ldots, n$ for a predefined contractual duration $T_{d}$ are $z c_{j}=z c_{j}^{0}+T_{d}-T_{\min }$. The existing total float of paths in the baseline schedule should be redistributed, in the form of buffers, among the processes according to the process weights calculated as follows:

$$
w_{j}=c_{j} \cdot k_{j}
$$

2. Calculate buffer sizes - to do so, find solution of the following model:

$$
\max z: z=\min _{j \in H}\left\{\frac{\delta_{j}}{z c_{j} \cdot w_{j}}\right\}
$$




$$
\begin{gathered}
s_{1}=0 \\
s_{j}-\delta_{j} \geq s_{i}+d_{i}, \forall(i, j) \in E \\
s_{n}+d_{n} \leq T_{d} \\
s_{j} \geq 0, \forall j \in V \\
\delta_{j} \geq 0, \forall j \in V \\
\delta_{j}=0, \quad \forall j \in V \backslash H \\
\delta_{j} \in \text { int, } \forall j \in H,
\end{gathered}
$$

where: $\quad H=\left\{j: w_{j}>0\right\}-$ a set of processes to be assigned buffers, $s_{j}$ - the start date of a process $j, j=1,2, \ldots, n$, in a buffered robust schedule.

The objective function (12) maximizes the value of the proposed surrogate measure of robustness. Conditions (13) and (14) enable the planner to calculate process starts in the buffered schedule. Project completion time cannot be exceeded (15).

The objective function as above provides solutions superior to solutions obtainable by means of methods presented in the literature this was confirmed by verification tests presented in [10].

Additionally, the presented approach puts forward two alternative surrogate measures of schedule robustness:

$$
\begin{aligned}
& \min _{j \in H}\left\{\frac{\delta_{j} \cdot p_{j}}{z c_{j} \cdot w_{j}}\right\}, \\
& \min _{j \in H}\left\{\frac{\delta_{j}}{z c_{j} \cdot c_{j}}\right\} .
\end{aligned}
$$

5. Structural steelwork frame A

6. Roof A

7. Cladding A

8. Floor bed A

9. Earthwork B

10. Foundation B

11. Building assembly B

12. Excavation $\mathrm{C}$

13. Foundation $\mathrm{C}$

14. Pref. rainforced concrete $C$

15. Brickwork C

16. Roof structure and covering $\mathrm{C}$

17. Connection to water mains

18. Connection to electrical mains

19. Roads and pavement

20. END

100

time [days]

$\begin{array}{llllll}50 & 100 & 150 & 200 & 250 & 300\end{array}$

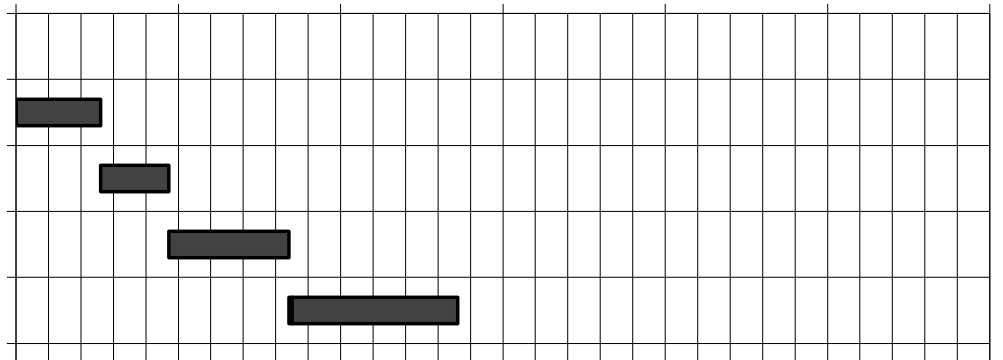

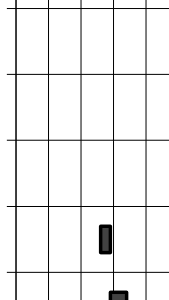
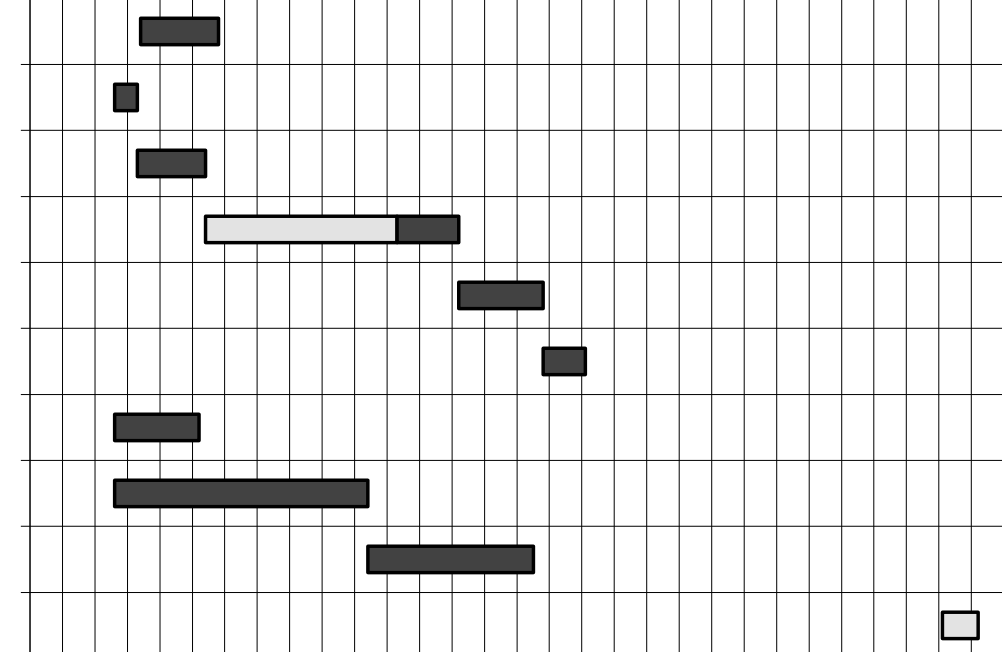

Fig. 6. Robust schedule with time buffers for the example; gray bars represent buffers located before the start of processes. 
where: $\quad p_{j}$ - number of process $j$ in the sequence of processes of total float $z c_{j}$, whose $c_{j}>0$, and that belong to the same path.

Formula (20) allows for the location of a process on a path, and thus it allows for reduction of a process's criticality by preceding buffers that compensate for some part of disturbance.

The quality of the proposed surrogate measures of robustness was checked for a series of contractual project durations assumed for the same case. The network model of this case is shown in Figure 5. The tests were conducted for five sets of unit costs of process delays (results obtained for one of these sets were presented in [12]).

Figure 6 presents the outcome for this case - a robust schedule created on the following assumptions: unit costs of process start de-

lays are $c_{5}=1, c_{7}=3, c_{14}=5, c_{20}=10$, unit costs of process start delays for the remaining processes equal 0 , the contractually agreed project duration is $T_{d}=292$. Buffer sizes, calculated as previously described, are as follows: $\delta_{5}=1, \delta_{7}=3, \delta_{14}=59, \delta_{20}=11$. The total instability cost of the schedule is $C=2.69$. This solution (with lowest instability cost) was obtained for the surrogate measure of robustness described by Formula 20.

The results gave grounds for the following conclusions:

1. The scale of schedule instability cost is strongly affected by the allowed time for completion; the longer the contractual duration and process floats, the more robust the schedule.

2. Increasing the project buffer placed in the network before the project completion date, and reducing buffers that protect intermediate dates implicates increased schedule instability cost.

3. Lowest schedule instability costs were obtained in schedules of relatively high unit costs of process start delay for intermediate dates. Thus, there are grounds to claim that buffers placed before intermediate dates are of higher schedule protecting potential and may efficiently reduce propagation of disturbance.

4. Measures of schedule robustness (12), (20) and (21) are of the same family of functions of the following general form:

$$
\min _{j \in H}\left\{\alpha\left(p_{j}\right) \cdot \frac{\delta_{j}}{z c_{j} \cdot w_{j}}\right\},
$$

where $\alpha\left(p_{j}\right)$ - a parameter whose value depends on the process's position in the path of a network model.

Application of the set of measures (12), (20) and (21) enables the user - in the case that the solutions do not satisfy the decision maker to reduce the extend of values of this parameter in the search for more robust schedules.

\section{Conclusions}

In the practice of construction management, there is a demand for scheduling methods integrated with risk management procedures $[25,26]$. In particular, support for quantitative analyses for risk management (typically with lack of objective input but expected to offer reliable basis for decisions) would be most welcome by the industry. Improving schedule reliability is especially important in the case of unique, unrepeatable projects such as modernisation and refurbishment of facilities that stay operational during construction works.

The paper presented the methodology for creating robust construction schedules based on the idea of buffering - allocating a block of time along network paths to protect due dates. A robust schedule of a predefined completion date minimizes instability cost (i.e. expected value of delaying process starts) and offers higher probability of meeting deadlines (i.e. reliability).

The main results of research on developing and refining the methodology are:

1) Implementing the robust scheduling concept to construction scheduling, in particular:

- providing practical measures of schedule robustness and a scheduling algorithm of low computational complexity,

- defining process criticality in risky environment,

- providing decision support for any stage of risk management process (integrated character of methodology).

2) Developing a methodology for risk level assessment that is based on an analysis of overall project operating conditions.

3) Developing a methodology for defining distribution parameters for process durations at various operating conditions; the method was applied to simulation research and to assessing quality of schedule improvement options.

4) Developing a fuzzy extension to AHP to support group decision making process, applicable in many fields of construction. The method improves objectivity of judgment, and can be used even if expert opinions are seriously discordant.

As the schedule instability cost is dependent upon the scale of the float of a sequence of processes distributed in the form of buffers, the author argues for developing scheduling methods aimed at minimizing project duration by means of soft logic [30], multi-skilling [5, 7], enabling changes of the sequence of the crew's migrating from location to location [4], and process duration crashing [22]. Applying them in combination with the proposed methodology will considerably improve construction schedules reliability.

\section{Acknowledgments:}

The paper is financially supported by Ministry of Science and Higher Education S/63/2015.

\section{References}

1. Al-Fawzan M. A., M. Haouari M. A bi-objective model for robust resource-constrained project scheduling. International Journal of Production Economics 2005; 96(2): 175-187, http://dx.doi.org/10.1016/j.ijpe.2004.04.002.

2. Bertsimas D., Sim M. The Price of Robustness. Operations Research 2004; 52(1): 35-53, http://dx.doi.org/10.1287/opre.1030.0065.

3. Bożejko W., Hejducki Z., Wodecki M. Applying metaheuristic strategies in construction projects management. Journal of Civil Engineering and Management 2012; 18(5): 621-630, http://dx.doi.org/10.3846/13923730.2012.719837.

4. Bożejko W., Hejducki Z., Uchroński M., Wodecki M. Solving resource-constrained construction scheduling problems with overlaps by metaheuristic. Journal of Civil Engineering and Management 2014; 20(5): 649-659, http://dx.doi.org/10.3846/13923730.2014.906496.

5. Burleson R. C., Hass C. T., Tucker R. L., Stanley A. Multiskilled labor utilization strategies in construction. Journal of Construction Engineering and Management 1998; 124(6): 480-489, http://dx.doi.org/10.1061/(ASCE)0733-9364(1998)124:6(480). 
6. Dawood N. Estimating project and activity duration: a risk management approach using network analysis. Construction Management and Economics 1998; 16(1): 41-48, http://dx.doi.org/10.1080/014461998372574.

7. Hegazy T., Shabeeb A. K., Elbeltagi E., Cheema T. Algorithm for scheduling with multiskilled constrained resources. Journal of Construction Engineering and Management 2000; 126(6): 414-421, http://dx.doi.org/10.1061/(ASCE)0733-9364(2000)126:6(414).

8. Hoła B., Schabowicz K. Estimation of earthworks execution time cost by means of artificial neural networks. Automation in Construction 2010; 19(5): 570-579, http://dx.doi.org/10.1016/j.autcon.2010.02.004.

9. Jaśkowski P., Biruk S., Bucoń R. Assessing contractor selection criteria weights with fuzzy AHP method application in group decision environment. Automation in Construction 2010; 19(2): 120-126, http://dx.doi.org/10.1016/j.autcon.2009.12.014.

10. Jaśkowski P., Biruk S. The method for improving stability of construction project schedules through buffer allocation. Technological and Economic Development of Economy 2011; 17(3): 429-444, http://dx.doi.org/10.3846/20294913.2011.580587.

11. Jaśkowski P., Biruk S. The conceptual framework for construction project risk assessment. Reliability: Theory \& Applications 2011; 2(3): 27-35.

12. Jaśkowski P., Biruk S., Kowalski T. Trade-off between robustness of a construction schedule and project completion time. International Journal of Arts \& Sciences 2011; 20(4): 205-215.

13. Jaśkowski P., Biruk S., Painting N. Using of fuzzy AHP for assessing risk of construction projects. International Journal of Arts \& Sciences 2011; 19(4): 257-268.

14. Jaworski K. M. Metodologia projektowania realizacji budowy (Methodology of planning construction works). Warsaw: Wydawnictwo Naukowe PWN, 1999.

15. Johnson D. The triangular distribution as a proxy for beta distribution in risk analysis. The Statistician 1997; 46(3): 387-398, http://dx.doi. org/10.1111/1467-9884.00091.

16. Kapliński O. Planning instruments in construction management. Technological and Economic Development of Economy 2008; 14(4): 449451, http://dx.doi.org/10.3846/1392-8619.2008.14.449-451.

17. Kasprowicz T. Inżynieria przedsięwzięć budowlanych (Construction project engineering). Radom-Warsaw: Wydawnictwo i Zakład Poligrafii Instytutu Technologii Eksploatacji, 2002.

18. Marcinkowski R. Metody rozdziału zasobów realizatora w działalności inżynieryjno-budowlanej (Contractor's resource assignment in construction and civil engineering). Warsaw: Military University of Technology, 2002.

19. Nasir D., McCabe B., Hartono L. Evaluating risk in construction-schedule model (ERIC-S): construction schedule risk model. Journal of Construction Engineering and Management 2003; 129(5): 518-527, http://dx.doi.org/10.1061/(ASCE)0733-9364(2003)129:5(518).

20. Połoński M., Pruszyński K. Impact of baseline terms on the course of critical paths and time buffers in the modified Goldratt's method. Archives of Civil Engineering 2013; 59(3): 313-320, http://dx.doi.org/10.2478/ace-2013-0017.

21. Rybka I., Bondar-Nowakowska E., Połoński M. The influence of stoppages on productivity during construction of water supply and sewage systems. Technical Transactions 2014; 2-B(6): 309-315.

22. Sakellaropoulos S., Chassiakos A. P. Project time-cost analysis under generalised precedence relations. Advances in Engineering Software 2004; 35(10-11): 715-724, http://dx.doi.org/10.1016/j.advengsoft.2004.03.017.

23. Samson S., Reneke J. A., Wiecek M. M. A review of different perspectives on uncertainty and risk and alternative modelling paradigm. Reliability Engineering and System Safety 2009; 94(2): 558-567, http://dx.doi.org/10.1016/j.ress.2008.06.004.

24. Schabowicz K., Hoła B. Application of artificial neural networks in predicting earthmoving machinery effectiveness ratios. Archives of Civil and Mechanical Engineering 2008; 8(4): 73-84, http://dx.doi.org/10.1016/S1644-9665(12)60123-X.

25. Schatteman D., Herroelen W., Van de Vonder S., Boone A. Methodology for integrated risk management and proactive scheduling of construction projects. Journal of Construction Engineering and Management 2008; 134(11): 885-893, http://dx.doi.org/10.1061/(ASCE)07339364(2008)134:11(885).

26. Skorupka D. Identification and initial risk assessment of construction projects in Poland. Journal of Management in Engineering 2008; 24(3): 120-127, http://dx.doi.org/10.1061/(ASCE)0742-597X(2008)24:3(120).

27. Taroun A., Yang J. B., Lowe D. Construction risk modeling and assessment: insights from a literature review. Journal of the Built \& Human Environment 2011; 4(1): 87-97.

28. Van de Vonder S., Demeulemeester E., Leus R., Herroelen W. The use of buffers in project management: The trade-off between stability and makespan. International Journal of Production Economics 2005; 97(2): 227-240, http://dx.doi.org/10.1016/j.ijpe.2004.08.004.

29. Van de Vonder S., Demeulemeester E., Herroelen W. Proactive heuristic procedures for robust project scheduling: an experimental analysis. European Journal of Operational Research 2008; 189(3): 723-733, http://dx.doi.org/10.1016/j.ejor.2006.10.061.

30. Wang W. - Ch. Impact of soft logic on the probabilistic duration of construction projects. International Journal of Project Management 2005; 23(8): 600-610, http://dx.doi.org/10.1016/j.ijproman.2005.05.008.

31. Williams C. A., Heins R. M. Risk management and insurance. New York: McGraw-Hill Book Co., 1971.

Piotr JAŚKOWSKI

Faculty of Civil Engineering and Architecture

Lublin University of Technology

ul. Nadbystrzycka 40, 20-816 Lublin, Poland

E-mail: p.jaskowski@pollub.pl 